(c) American Dairy Science Association, 2006.

\title{
Dopamine Antagonist Alters Serum Cortisol and Prolactin Secretion in Lactating Holstein Cows
}

\author{
A. Ahmadzadeh,, ${ }^{1,2}$ M. A. Barnes, F. C. Gwazdauskas, and R. M. Akers \\ Department of Dairy Science, Virginia Polytechnic Institute and State University, Blacksburg 24061
}

\begin{abstract}
The role of dopamine in regulating glucocorticoid and prolactin secretion was investigated in lactating Holstein cows by characterizing serum cortisol and prolactin responses to fluphenazine, a dopamine receptor antagonist. Twelve anovulatory cows received an intravenous bolus injection of either saline $(\mathrm{n}=6)$ or $0.3 \mathrm{mg}$ of fluphenazine $/ \mathrm{kg}$ of body weight $(\mathrm{n}=6)$ in wk 2 postpartum. Blood samples were collected every $30 \mathrm{~min}$ for $4 \mathrm{~h}$ before and $4 \mathrm{~h}$ after saline or fluphenazine injection. Serum progesterone concentration was $0.13 \pm 0.1 \mathrm{ng} /$ $\mathrm{mL}$ and did not differ between groups. No difference in serum cortisol concentrations was detected between groups before treatments. Fluphenazine increased serum cortisol concentrations within $30 \mathrm{~min}$ after fluphenazine administration $(>30 \mathrm{ng} / \mathrm{mL})$ and concentrations remained elevated throughout the sampling period. Cortisol remained unchanged in saline-treated cows $(<10 \mathrm{ng} / \mathrm{mL})$. Prolactin concentrations also increased after fluphenazine administration (103.1 \pm 3.1 $\mathrm{ng} / \mathrm{mL})$, but were unaffected by saline $(18 \pm 3.1 \mathrm{ng} / \mathrm{mL})$. Prolactin concentrations remained elevated throughout the sampling period in fluphenazine-treated cows. Our results indicated that a dopamine antagonist increased cortisol, suggesting that endogenous dopamine, at least in part, regulates cortisol and prolactin secretion. These effects are regulated through dopamine receptors in anovulatory lactating dairy cows during the early postpartum period.
\end{abstract}

Key words: dopamine, glucocorticoid, dairy cow, fluphenazine

\section{INTRODUCTION}

In dairy cows glucocorticoids are an important component of many physiological functions including metabolism, mammogenesis, lactogenesis, and galactopoiesis (Akers et al., 1981; Akers, 1990). Glucocorticoids are

Received October 4, 2005.

Accepted January 17, 2006.

${ }^{1}$ Corresponding author: amin@uidaho.edu

${ }^{2}$ Current address: PO Box 442330, University of Idaho, Moscow 83844-2330. also involved with glycogen deposition in liver and lipolysis, and are associated with the immune system, stress, and thermal regulation. Evidence exists that dopamine regulates cortisol secretion in ewes (Sowers et al., 1983), women (Boesgaard et al., 1990), and dogs (Kooistra et al., 1997). Browning et al. (2000) showed that ergotamine, an ergot alkaloid with dopamine-like activity, increased cortisol secretion in yearling steers and heifers. Ergotamine, however, can interact with various biogenic amine neurotransmitters including $\alpha$ adrenergic and serotonergic systems as well (Silberstein, 1997), making it difficult to identify the ergotamine mode of action and the bioaminergic system that is affected by this ergot alkaloid (Browning et al., 2000). Thus, it is not clear whether the ergotamine-induced increase in cortisol secretion is mediated through a dopaminergic pathway in cattle.

The specific role of dopamine in the regulation of glucocorticoid secretion in cattle is not fully understood because no reports are found in the literature regarding the effect of dopamine or its specific antagonist on cortisol secretion in lactating cows. Therefore, our objective was to investigate the role of dopamine in regulating glucocorticoid secretion in lactating dairy cows by characterizing serum cortisol responses to fluphenazine (FLU), a specific dopamine receptor antagonist. Furthermore, because it has been shown that dopamine inhibits prolactin secretion (Benoit et al., 1986; Johnson et al., 1991; Malven, 1993), serum prolactin concentrations were measured in response to FLU as a positive control to confirm that dopamine receptors were effectively blocked.

\section{MATERIALS AND METHODS}

Twelve early postpartum (d 13 or 14) lactating Holstein cows from the Virginia Tech Dairy Center (Blacksburg, VA) were used in this experiment. The experiment was conducted from February through April. Beginning at parturition, all cows were fed a TMR balanced to meet or exceed nutrient requirements for lactating cows to produce $40 \mathrm{~kg}$ of milk/d according to $\mathrm{NRC}$ recommendations $\left(\mathrm{DM}=53 \%, \mathrm{CP}=17.4 \%, \mathrm{ADF}=20 \%, \mathrm{NE}_{\mathrm{L}}=\right.$ $1.68 \mathrm{Mcal} / \mathrm{kg}$ ). All cows were weighed, and their ovaries examined by transrectal ultrasound on the day before 
the experiment began. Subsequently, cows were fitted with jugular catheters (Johnson et al., 1991) and assigned randomly to receive either $0.9 \%$ saline $(n=6)$ or $0.3 \mathrm{mg}$ of FLU (Sigma Chemical Corp., St. Louis, MO) per $\mathrm{kg}$ of BW $(\mathrm{n}=6)$. This dose of FLU was smaller than that $(0.5 \mathrm{mg} / \mathrm{kg} \mathrm{BW})$ used in anestrous ewes (Meyer and Goodman, 1986) and determined to be effective based on previous findings (Ahmadzadeh et al., 1996). Fluphenazine was dissolved in $10 \mathrm{~mL}$ of physiological saline. On d 13 or 14 postpartum, beginning at $0500 \mathrm{~h}$ and at least $1 \mathrm{~h}$ after milking, blood samples were collected at 30-min intervals for $4 \mathrm{~h}$ before and 4 $\mathrm{h}$ after FLU or saline. Blood samples were placed in ice immediately after collection and then stored at $4{ }^{\circ} \mathrm{C}$ for $24 \mathrm{~h}$ to allow clotting. Blood samples were centrifuged for $30 \mathrm{~min}$ at $2,200 \times \mathrm{g}$ at $4^{\circ} \mathrm{C}$. Serum was harvested and aliquots stored at $-20^{\circ} \mathrm{C}$ until concentrations of cortisol, prolactin, and progesterone were determined. During blood sampling all cows were tied in individual stalls with ad libitum access to a TMR and water. All experimental protocols used in this experiment were approved by the Animal Care and Use Committee.

\section{Hormone Assays}

Serum cortisol (Browning et al., 1998, 2000) and progesterone were measured using solid-phase radioimmunoassay (Diagnostic Products Corp., Los Angeles, CA). Assay of cortisol was performed in nonequilibrium conditions to increase the sensitivity of the assay. The standard curve ranged from 2.5 to 200 to $\mathrm{ng} / \mathrm{mL}$. Samples were run in duplicate in a single assay and the intraassay CV were 4.6 and $4.1 \%$, for cortisol and progesterone, respectively. Concentration of prolactin was determined by a double-antibody radioimmunoassay (Barnes et al., 1985). All samples were assayed in duplicate and the intra- and interassay coefficients of variation were 6 and $14.4 \%$, respectively.

\section{Statistical Analyses}

Analyses of repeated measures of serum cortisol and prolactin, using the mixed model procedure of SAS (Littell et al., 1998), were utilized. The statistical model included treatment, the repeated factor time, and treatment $\times$ time interaction. Cow within treatment was designated as a random effect and mean pretreatment hormone concentrations were used as covariates in the model.

\section{RESULTS}

Results of ultrasonography, conducted on the day before the experiment, verified the absence of a corpus luteum in all cows. None of the cows exhibited estrus before or on the day of experiment. Mean serum concentration of progesterone was $0.13 \pm 0.08 \mathrm{ng} / \mathrm{mL}$.

Mean serum prolactin concentrations did not differ between groups during the pretreatment period (Figure 1). Fluphenazine elicited a nearly 7 -fold increase $(P<$ $0.01)$ in prolactin concentrations ( $14.4 \pm 3.1$ before FLU vs. $103.1 \pm 3.1 \mathrm{ng} / \mathrm{mL}$ after FLU). Mean prolactin concentrations remained elevated throughout the remainder of the sampling period (Figure 1). Prolactin concentrations remained unchanged in saline-treated cows $(18.4 \pm 3.1 \mathrm{ng} / \mathrm{mL}$ pretreatment vs. $17.9 \pm 3.1 \mathrm{ng} / \mathrm{mL}$ posttreatment). These results indicate that the dose of FLU was sufficient to block dopamine receptors.

Fluphenazine elicited an increase $(P<0.05)$ in serum cortisol concentrations (Figure 2). Mean serum cortisol concentrations were similar for saline- and FLUtreated animals during the pretreatment period. Cortisol concentrations increased by nearly 3 -fold $(P<0.01)$ after FLU administration, and remained elevated $(P<$ 0.05) during the posttreatment period compared with saline. Saline administration did not affect cortisol concentrations (Figure 2). Four cows had an immediate increase in cortisol within 30 min after FLU administration and 2 remaining cows had an increase in cortisol $1 \mathrm{~h}$ after FLU injection. All FLU-treated cows showed some behavioral changes in response to treatment. Approximately 20 min after FLU treatments, cows became immobile and showed some muscle tremors and abnormal chewing behavior. These responses lasted for approximately $2 \mathrm{~h}$ after FLU, and thereafter, no further abnormal behavior was observed.

\section{DISCUSSION}

A bolus injection of dopamine antagonist, FLU, significantly increased serum prolactin concentrations in all FLU-treated cows. The effect of FLU on serum prolactin lasted through the experimental period because of the long duration of action of FLU, which is estimated to have a half-life of $16 \mathrm{~h}$ in human plasma (Dysken et al., 1981). Release of prolactin from the anterior pituitary is chronically inhibited by hypothalamic dopamine (Malven, 1993) as evidenced by dopamine agonist suppression of prolactin secretion in cattle (Benoit et al., 1986; Johnson et al., 1991). Our results demonstrated that the dose of FLU used was sufficient to antagonize dopamine action.

Results of these experiments indicated that dopamine antagonist (FLU; $0.3 \mathrm{mg} / \mathrm{kg}$ of BW) significantly increased serum cortisol concentrations in the anovulatory postpartum dairy cow (Figure 2). This the first study to show that glucocorticoid secretion in cattle is regulated, in part, by the dopaminergic system and via 


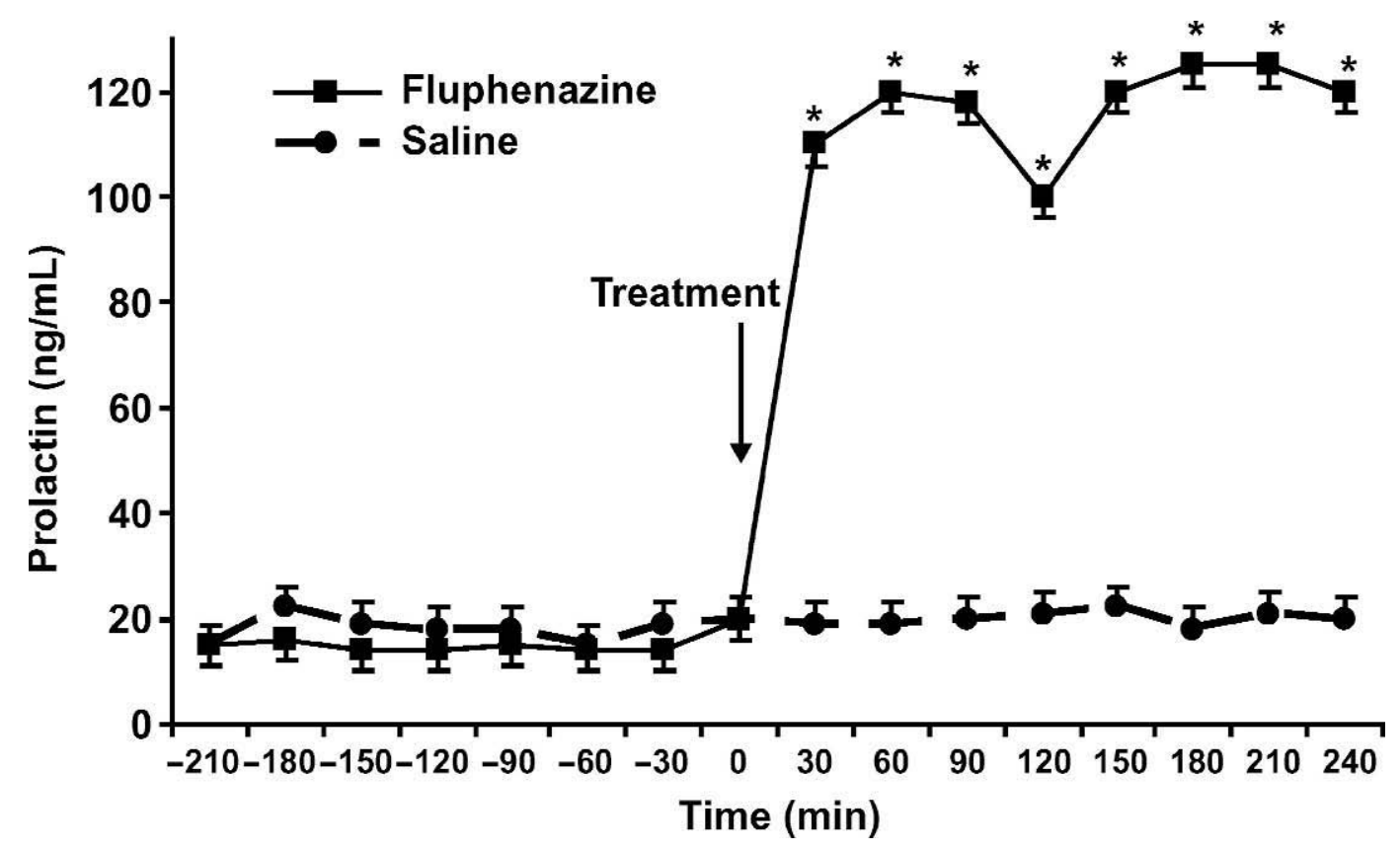

Figure 1. Serum concentrations of prolactin (mean \pm SE) for Holstein cows before and after injection of either saline $(n=6)$ or fluphenazine $(0.3 \mathrm{mg}$ per $\mathrm{kg}$ of $\mathrm{BW})$ on d 13 or 14 postpartum. *Means differ $(P<0.05)$ from saline-treated cows.

dopamine receptors. Because FLU negates the action of dopamine by blocking dopamine receptors, the increase in cortisol secretion after FLU administration indicates that endogenous dopamine inhibits cortisol secretion in anovulatory dairy cows. Our results are in agreement with reports in ewes (Sowers, et al., 1983;

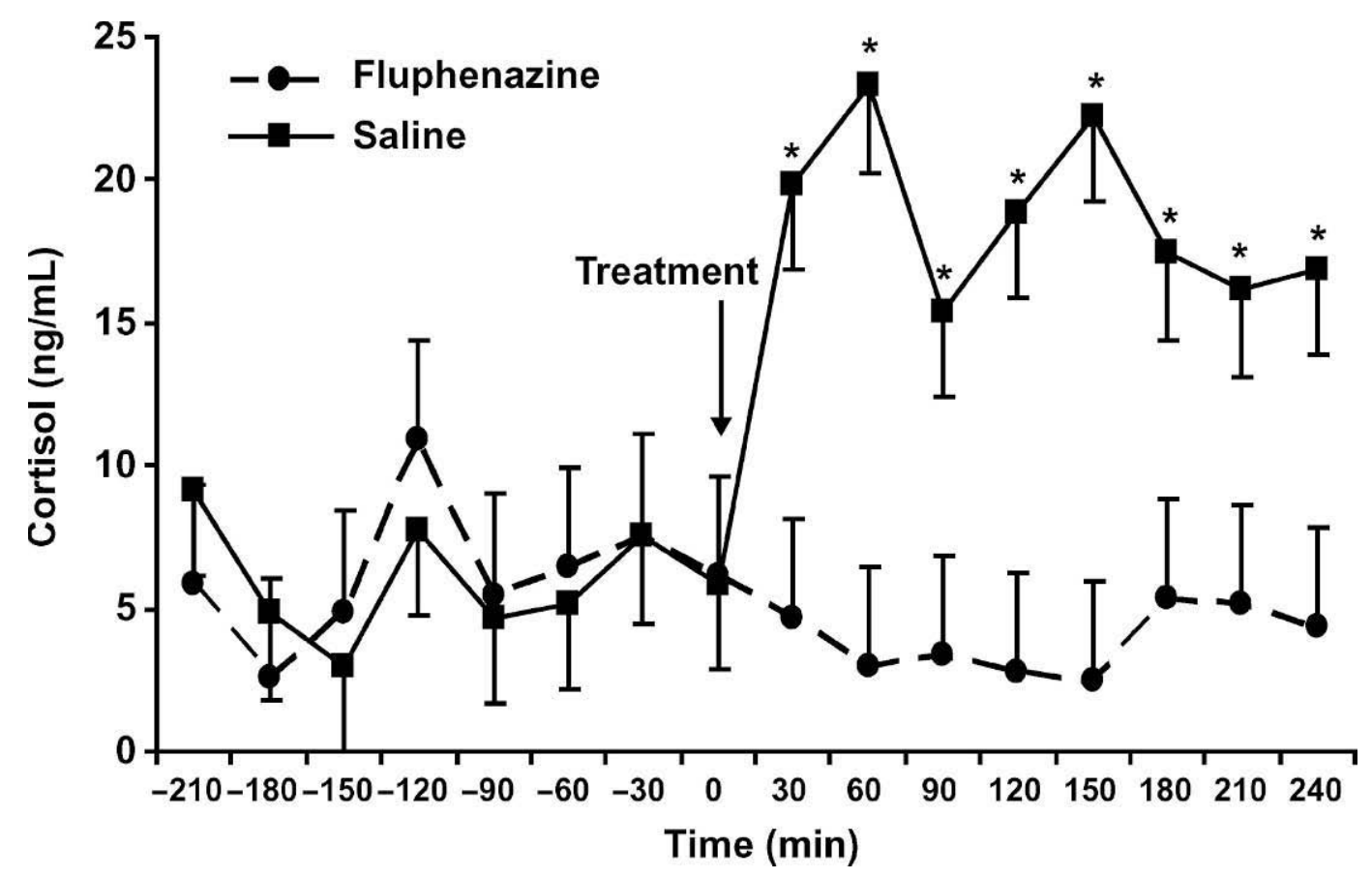

Figure 2. Serum concentrations of cortisol (mean \pm SE) for Holstein cows before and after injection of either saline ( $\mathrm{n}=6)$ or fluphenazine $(0.3 \mathrm{mg}$ per $\mathrm{kg}$ of BW) on d 13 or 14 postpartum. *Means differ $(P<0.05)$ from saline-treated cows. 
Cameron et al., 1987), in women experiencing hypothalamic amenorrhea (Seki et al., 1997), and in normal women (Boesgaard et al., 1990), collectively showing that metocloparamide, a D2 dopamine receptor antagonist, increased cortisol secretion. Similarly, a dopamine receptor antagonist, haloperidol, and a D1 receptor antagonist (SCH23390) stimulated cortisol secretion in dogs (Goiny et al., 1986; Kooistra et al., 1997). In contrast to the present study, it was shown that ergotamine, an ergot alkaloid with dopamine-like activity, increased plasma cortisol in steers and cows (Browning et al., 1998, 2000), indicating that dopamine may stimulate cortisol secretion; however, there is a substantial difference between the pharmacological agents used, which may explain the observed dissimilarity between the present study and the results of Browning et al. $(1998,2000)$. Ergotamine exhibits partial agonistic and antagonistic actions on $\alpha$-adrenergic, dopaminergic, and serotonergic receptors (Muller-Schweinitzer and Weidmann, 1978; Rall and Schlefer, 1980), whereas FLU is considered a specific dopamine receptor antagonist (Morgan and Finch, 1986). Therefore, the increase in cortisol secretion by ergotamine, observed by Browning et al. (2000), may have occurred because of the interaction of this drug with various biogenic amine neurotransmitters and their receptors such as $\alpha$-adrenoreceptors and serotonergic systems (Browning et al., 2000) and not the dopamine system.

Our results indicate that dopaminergic mechanisms are involved in the regulation of cortisol secretion in the anovulatory lactating dairy cow. The site of the stimulatory action of FLU on cortisol secretion (hypothalamic-pituitary-adrenal axis) and the involved dopamine receptor subtype cannot be determined from our study. Fluphenazine binds to both D1 and D2 subtype dopamine receptors (Karlsson et al., 1988), but it has been reported to have a greater affinity for D1 receptors (Jensen and Daw, 1986; Sawaguchi et al., 1990). In vitro studies showed that no specific D1 receptors are detectable in sections of the human adrenal cortex (Amenta et al., 1994). Furthermore, light microscopic autoradiography in humans showed a high density of specific D2 receptor binding sites only in the zona glomerulosa and only sparse D2 binding sites localized in the zona fasciculata, which is thought to be the primary site of glucocorticoid secretion (Amenta et al., 1994). Moreover, Bird et al. (1998) showed that dopaminergic stimulation of cortisol secretion from bovine zona fasciculata and reticularis cells occurs through nonspecific stimulation of adrenergic $\beta$-receptors and not dopaminergic receptors. The results of previous research (Ahmadzadeh et al., 1998) showed that the same dose of FLU decreased pulse frequency and concentrations of LH in a similar group of cows. Know- ing that LH pulses in the peripheral blood correspond with GnRH pulses (Thiery and Martin, 1991), and that FLU can penetrate the blood-brain barrier (Meyer and Goodman, 1986), suppression of pulse frequency and concentrations of LH may provide additional evidence that the site of FLU action is likely the hypothalamicpituitary axis. The observed increase in prolactin after FLU administration in the current study supports this hypothesis. Nonetheless, the stimulatory action of FLU on sites other than the hypothalamic-pituitary axis cannot be ruled out. More studies are required to examine the role of dopamine in modulation of both ACTH and glucocorticoid secretion during various stages of lactation and phases of the estrous cycle and to identify the site of dopamine action in cattle.

\section{CONCLUSIONS}

In summary, we provide the first evidence that a specific dopamine antagonist increases cortisol secretion in anovulatory lactating dairy cows on d 14 or 15 postpartum. These findings support the idea that endogenous dopamine plays a part in the control of cortisol secretion during the anovulatory early postpartum period and thus, may be involved in cortisol-related physiological functions such as stress, metabolism, lactogenesis, and lipolysis.

\section{REFERENCES}

Ahmadzadeh, A., M. A. Barnes, R. M. Akers, and F. C. Gwazdauskas. 1998. Involvement of dopamine in modulation of $\mathrm{LH}$ and prolactin secretion in anovulatory Holstein cows during the early postpartum period. J. Anim. Sci. 76(Suppl. 1):92. (Abstr.)

Ahmadzadeh, A., M. A. Barnes, R. M. Akers, F. C. Gwazdauskas, and M. L. McGilliard. 1996. Effect of dopamine antagonist on serum LH, FSH and prolactin secretion in lactating Holstein cows. J. Anim. Sci. 74(Suppl. 1):220. (Abstr.)

Akers, R. M. 1990. Lactation physiology: A ruminant animal perspective. Protoplasma 159:96-111.

Akers, R. M., D. E. Bauman, A. V. Capuco, G. T. Goodman, and H. A. Tucker. 1981. Prolactin regulation of milk secretion and biochemical differentiation of mammary epithelial cells in periparturient cows. Endocrinology 109:23-30.

Amenta, F., L. Chiandussi, M. Mancini, A. Ricci, M. Schena, and F. Veglio. 1994. Pharmacological characterization and autoradiographic localization of dopamine receptors in the human adrenal cortex. Eur. J. Endocrinol. 131:91-96.

Barnes, M. A., G. W. Kazmer, R. M. Akers, and R. E. Pearson. 1985. Influence of selection for milk yield on endogenous hormones and metabolites in Holstein heifers and cows. J. Anim. Sci. 60:271284.

Benoit, A. M., J. R. Molina, and L. L. Anderson. 1986. Prolactin secretion in cattle as affected by haloperidol and $\alpha$-methyl- $\rho$ tyrosine. Anim. Reprod. Sci. 13:239-248.

Bird, I. M., E. R. Lightly, M. Nicol, B. C. Williams, and S. W. Walker. 1998. Dopaminergic stimulation of cortisol secretion from bovine zfr cells occurs through nonspecific stimulation of adrenergic betareceptors. Endocr. Res. 24:769-772.

Boesgaard, S., C. Hagen, A. N. Andersen, M. Fenger, and E. Eldrup. 1990. Effect of dopamine, dopamine D-1 and D-2 receptor modulation on ACTH and cortisol levels in normal men and women. Acta Endocrinol. 122:29-36. 
Browning, R., Jr., S. J. Gissendanner, and T. Wakefield, Jr. 2000. Ergotamine alters plasma concentrations of glucagon, insulin, cortisol, and triiodothyronine in cows. J. Anim. Sci. 78:690-698.

Browning, R., Jr., M. L. Leite-Browning, H. M. Smith, and T. Wakefield, Jr. 1998. Effect of ergotamine and ergonovine on plasma concentrations of thyroid hormones and cortisol in cattle. J. Anim. Sci. 76:1644-1650.

Cameron, V., E. A. Espiner, M. G. Nicholls, and S. Parratt. 1987. Effect of metoclopramide on adrenal secretion in sheep: Influence of dexamethasone and sodium intake. J. Steroid Biochem. 26:717-721.

Dysken, M. W., J. I. Javaid, S. S. Chang, C. Schaffer, A. Shahid, and J. M. Davis. 1981. Fluphenazine pharmacokinetics and therapeutic response. Psychopathology 73:205-210.

Goiny, M., M. Herrera-Marschitz, K. Uvnas-Moberg, S. Cekan, U. Ungerstedt, and N. Schmiedebergs. 1986. The benzazepine SCH 23390 increases plasma levels of cortisol in the conscious dog. Arch. Pharmacol. 332:111-112.

Jensen, R. J., and N. W. Daw. 1986. Effects of dopamine and its agonists and antagonists on the receptive field properties of ganglion cells in the rabbit retina. Neuroscience 17:837-855.

Johnson, D. W., M. A. Barnes, R. M. Akers, and R. E. Pearson. 1991. Exogenous opioids increase plasma prolactin in Holstein calves primarily via a dopaminergic mechanism. J. Anim. Sci. 69:4545-4551.

Karlsson, G., A. L. Jaton, and J. M. Vigouret. 1988. Dopamine D1and D2-receptor interaction in turning behaviour induced by dopamine agonists in 6-hydroxydopamine-lesioned rats. Neurosci. Lett. 88:69-74.

Kooistra, H. S., S. H. Greven, J. A. Mol, and A. Rijnberk. 1997. Pulsatile secretion of alpha-MSH and the differential effects of dexamethasone and haloperidol on the secretion of alpha-MSH and ACTH in dogs. J. Endocrinol. 152:113-121.
Littell, R. C., P. R. Henry, and C. B. Ammerman. 1998. Statistical analysis of repeated measures data using SAS. J. Anim. Sci. 76:1216-1231.

Malven, P. V. 1993. Prolactin. Pages 119-140 in Mammalian Neuroendocrinology. P. V. Malven, ed. CRC Press, Boca Raton, FL.

Meyer, S. L., and R. L. Goodman. 1986. Separate neural systems mediate the steroid-dependent and steroid-independent suppression of tonic luteinizing hormone secretion in the anestrous ewe. Biol. Reprod. 35:562-571.

Morgan, D. G., and C. E. Finch. 1986. $\left[{ }^{3} \mathrm{H}\right]$ Fluphenazine binding to brain membranes: Simultaneous measurement of D-1 and D-2 receptor sites. J. Neurochem. 46:1623-1631.

Muller-Schweinitzer, E., and H. Weidmann. 1978. Basic pharmacological properties. Pages 87-232 in Handbook of Experimental Pharmacology. Ergot Alkaloids and Related Compounds. Vol. 49 B. Berde and H. O. Schild, ed. Springer-Verlag, Berlin, Germany.

Rall, T. W., and L. S. Schlefer. 1980. Drugs affecting uterine motility: Oxytocin, prostaglandins, ergot alkaloids, and other agents Pages 935-950 in The Pharmacological Basis of Therapeutics. 6th ed. A. G. Gilman, L. S. Goodman, and A. Gilman, ed. Macmillan Publishing Co., New York, NY.

Sawaguchi, T., M. Matsumura, and K. Kubota. 1990. Effects of dopamine antagonists on neuronal activity related to a delayed response task in monkey prefrontal cortex. J. Neurophysiol. 63:1401-1412

Silberstein, S. D. 1997. The pharmacology of ergotamine and dihydroergotamine. Headache 37(Suppl. 1):S15-S25.

Sowers, J. R., F. W. Beck, N. Stern, and N. Asp. 1983. Effects of metoclopramide on plasma corticosteroid levels in sheep. Endocrinology 113:903-906.

Seki, K., T. Kato, and S. Sekiya. 1997. Corticotrophin and vasopressin responses to metoclopramide in patients with hypothalamic amenorrhoea. Clin. Endocrinol. 46:203-207.

Thiery, J. C., and G. B. Martin. 1991. Neurophysiological control of the secretion of gonadotrophin-releasing hormone and luteinizing hormone in the sheep-A review. Reprod. Fertil. Dev. 3:137-173. 